\title{
Attribution of Liability among Multiple Tortfeasors under Negligence Law: Causation in Iran and England
}

\author{
Elyas Noee ${ }^{1}$, Mohammad Noee ${ }^{2} \&$ Azadeh Mehrpouyan $^{3}$ \\ ${ }^{1}$ Department of Law, Central Tehran Branch, Islamic Azad University, Tehran, Iran \\ ${ }^{2}$ Department of Law, Ardabil Branch, Islamic Azad University, Ardabil, Iran \\ ${ }^{3}$ Young Researchers and Elite Club, Central Tehran Branch, Islamic Azad University, Tehran, Iran \\ Correspondence: Elyas Noee, Department of Law, Central Tehran Branch, Islamic Azad University, Tehran, Iran. \\ E-mail: elyas.noee@gmail.com
}

Received: June 9, 2016 Accepted: July 12, 2016 Online Published: August 30, 2016

doi:10.5539/jpl.v9n7p219 URL: http://dx.doi.org/10.5539/jpl.v9n7p219

\begin{abstract}
"Causation" possesses a considerable place in tort law of Iran and England particularly in the field of Negligence law. Existing differences in legal systems of Iran (as a Civil Law system) and England (as a Common Law system) make find a common perspective difficult to study causation but possible. This research focuses to compare causation in cases where more than one tortfeasors is involved in inflicting damage by negligence. This study also attempts to recognize differences and similarities between Iran and England in order to resolve ambiguities in Iran legal system through England legal system. The study was conducted in three sections including tortfeasors' indenpendancy, tortfeasors' contribution, and tortfeasors' separate impact. This paper reports respectively: in case of tortfeasor independency, Iran law admits jointly and severally liability while England law offers a variety of approaches in various cases; in case of tortfeasors' contribution, each tortfeasor is liable according to its effect on causing damage with few exceptions; and in case of tortfeasors' separate impact, per tortfeasor is liable for inflicted damage which is only from oneself side. The results show England law can be considered to filling legal gap of Iran law regarding present identified differences and similarities.
\end{abstract}

Keywords: causation, negligence, liability, damage, harm-causing factor

\section{Introduction}

Most of the liabilities which rise to recover losses are not with the nature of Strict Liability. Further, Intentional Torts compared to negligence does not allocate a noticeable amount of tort cases to itself. Therefore, most of the tort claims are about negligence. This matter causes negligence and its due liability receives more necessity than strict liability and intentional torts.

Most cases in which negligence has been committed, recognizing factor or factors caused damages are not difficult and the effective factors in damaging incidents can be determined. The difficulty begins with the need to determine the liable tortfeasor i.e. dealing with presence or absence of causal relation among the involving factors in damage. In other words, the hardship of investigation emerges in attributing liability to one or more involving factors; so through it, the liable factor or factors of the caused damage can be recognized. Addressing these issues might lead the discussion to "Causation".

The concept of causation faced some ambiguities (Hylton, 2013) and the best place to contemplate is in tort law (Meier, 2011). A stream of literature review survey show that a disagreement among Iranian lawyers and also English judges on tort law can be realized. The complexity and ambiguity of causation is gone so far that neither Iran ,as a system that counts legislation and rule-making as superior and preference, (Safai \& Rahimi, 2014) nor England ,as a system that stresses on Judicial decision-making and "case law", failed to cross this legal obstacle with full consent and reach a solution that is consensus.

Existing ambiguities in the law of Iran and England and applicability of issues on causation are the most important reason to conduct present comparative study. Besides, most case legal studies in Iranian researches focus on a comparative study with French law not English, due to the a large similarities of French and Iranian law. Although the differences exist between Iranian and English law, consulting English law is applicable in causation. Hence, this matter convinces present researchers to choose English law for current case study; it does 
not only avoid stereotypical study of the law of Iran and France but also it seeks to find new solutions that may be available only in the Common-Law legal family not the Civil Law.

Although some great Iranian scholars asserted some general implications to "causation" exist in law of England and USA (e.g. Katouzian, 2014; Safai \& Rahimi, 2014), but there are almost no books or articles discussing the comparative detailed study of causation and liability attribution in law of Iran and England; while, the study of causation in Iranian law has been discussed in the works of prominent lawyers of this country in detail (e.g. Safai \& Rahimi, 2014; Katouzian, 2014). In law of England, Cooke (2010) and USA, Stapleton (2010) examined the role of causation in realizing the negligence law of these two countries. In addition, other studies ( e.g. Hitchcock \& Stirling, 2012; Goepel \& Batkin, 2009) investigated causation in cases where more than one tortfeasor is involved in losses due to negligence, but the point of views of the mentioned studies to causation are somehow different from views of present article. Present study aims to study the interference of multiple tortfeasors involving in an accident in terms of their roles which may be independently, contributory or with separate impacts, not to limit ourselves solely to the law of Iran or England. Further, indivisibility or divisibility of the damages or being or not being the result of contributory negligence of the damages does not deal with the principal purpose of present study. In addition, in cases where only one tortfeasor is involved in the accident and the main scope is on his/her being or not being liable or a case in which only one tortfeasor has caused damage but it is impossible to identify that tortfeasor from other similar tortfeasors, is not considered either in this study.

The principal objective of present study is to examine the role of causation in law of Iran and England in cases which more than one tortfeasor are involved in the damages resulted by negligence. This study also investigates the differences and similarities of causation notion in order to enrich and address the shortcomings of Iranian tort law with a probable help of strategies proposed in law of England.

Regarding current differences between common law and civil law particularly Tort law, it is proposed no similarity exists between law of Iran with law of England in this field and nothing in common can be found between laws of these two countries. As a result, the strategies proposed in law of England won't or may not have the ability of being performed in Iranian law. Acceptance or rejection of this hypothesis has been investigated in this paper.

First, the position of causation in general tort law rules of Iran and England is discussed; hence, comparative studies were conducted on status of negligence in general tort law rules and then, position of causation in negligence. In the second section, causation is also discussed regarding an intervention manner of the tortfeasors involved in an incident, in three positions of independency of tortfeasors, contribution of tortfeasors and separate impact of the tortfeasors.

\section{Causation in Tort Law of Iran and England}

Before opening the main discussion, it is necessary to note the general rules of tort law of Iran and England briefly to determine the status of negligence in general rules of tort law first and then, status of causation in negligence.

\subsection{Status of Negligence in Tort Law}

Tortious liability is either of Fault-Based Liability or Strict Liability. In the law of England, liability is resulted from intention and negligence is studied under the subject of fault-based liability. Strict liability is also proposed in cases where mere inflict of damage causes liability, regardless of whether act of the person causing the loss is intentional or due to negligence. Cooke (2010) noted that instances of this type of liability in tort law are limited.

The concept fault has also a general meaning in Iranian tort law which is considered both in case of negligence of a person and his/her intention in causing damages. Accordingly, general rules of Iranian tort law, the same as England, are classified in two general categories of Fault-Based Liability and Strict Liability which the recent type of liability is emerged regardless the presence or absence of fault. Although general rules of tort law in Iran and England are almost identical, but unlike England, the negligence liability is rarely discussed independently in Iranian law. In other words, the fault-based liability in Iranian law is studied regardless the act is intentional or due to negligence of the defendant.

\subsection{Status of Causation in Negligence}

After studying the state of negligence in tort law of Iran and England, it is also necessary to determine the state of causation in negligence.

In order to succeed in a negligence action, three elements must be proved in law of England as follows: 1. Duty of care, 2. Breach of duty and 3. Damages. Two essential discussions arise in the study of the third element of 
negligence liability, namely occurrence of damage: the first one is "causation" and the second is "remoteness of damage".

Another side, negligence is not discussed in the study of general rules of Iranian tort law independently. As a result, the same elements proposed for tortious liability (including fault-based liability or strict liability) are also extended to negligence liability. Therefore, elements of tortious liability (and consequently negligence liability) in law of Iran is as follows: first, presence of damaging act or omission; second, occurrence of damage and third, presence of causal link between damaging act/omission and the occurred damage. Hence, the position of causation in negligence liability in Iranian law is not different with its position in a liability due to intentional inflict of damage or strict liability and it is not studied independently (Noee, 2015).

According to above-mentioned study, two main differences among the law of Iran and England can be determined. First, unlike England, causation is not independently studied in negligence liability of Iran. Secondly, unlike England, in Iranian law, causation is not studied under the title of damage occurrence and it is studied independently. However, a similarity exists between the law of the two countries which is, causation, regardless its study position, is a fixed concept in all fields of tort law and the rules governing it does not change based on type of responsibility, namely although causation is discussed under the title of negligence liability in law of England, but its rules are also extended to other fields of tort law in which a need emerges to prove damage occurrence (Elliot \& Quinn, 2009). On the contrary, causation in law of Iran is generally proposed for all fields of tort first and then the same general notion is also used in negligence liability like other fields of law.

This paper attempts to study the causal link in cases where multiple tortfeasors have been involved in the occurrence of damages independently, contributory or with separate impacts.

\section{Causation and Multiple Tortfeasors}

Technological progress in modern world has created changes in tort law and the occurrence of tortious acts that has caused situations in which one victim or claimant is placed in front of one defendant, to be replaced with situations where multiple factors are placed in front of multiple victims (Halbersberg, 2013). Causal link is studied under the title of "intervention of multiple factors". "Intervention of multiple factors" is proposed when scholars are able to determine the person or people in charge of the incident by relying on the existing standards among the different factors the involvement of which have been approved by law, and any reasonable person may see involvement of any of them reasonable.

It needs to be noted that Iranian lawyers have proposed different ideas to determine the cause responsible for this case. What the mentioned ideas have in common is that one standard can be used for all various states. Some notable researchers (e.g. Katouzian, 2014; Safai \& Rahimi, 2014) suggested the reasonable major cause as the person responsible for the damages to the damaged party and attribute the responsibility to him/her. While, others put the burden on the close and direct cause (Imami, 2011; Bahrami Ahmadi, 2010). Further, another group considers no authenticity for the proposed opinions and see the "Common Hostility" as being the base of determining the responsible cause (Qasemzadeh, 2010; Yazdanian, 2007). Although, ideas of the first group seem to be more consistent with justice, but since this view does not give a precise and clear criteria to determine causation link in various situations either, possible situations are required to be proposed carefully in order to identify which involved factor must be known as the reasonable major cause.

In law of England, cases in which more than one factor are involved in the occurrence of damage, British courts apply different methods to determine the main responsible and cause of the incident, which has resulted in not being able to predict a final result of the lawsuit. Nevertheless, some of the methods are more common and applicable in this field and some of the most important tests applied to determine the cause responsible for the incident are discussed below. ${ }^{1}$ It is notable that these tests are not in line with "but-for test" and they are even considered as an exception to it (Crowne \& Ha-Redeye, 2012).

\subsection{Tortfeasors' Independency}

Independency in causation discussion means the existence of independent causal link between acts or omissions of each tortfeasor involved with the damage occurred. In other words, each factor can independently cause damages. Therefore, there has been one damage in this case, but various factors can independently cause the mentioned damage.

\footnotetext{
${ }^{1}$ In this case, the most important test applied in law of USA and Canada respectively include "Substantial Factor" and "Material Contribution". The latter test became more significant in law of Canada from 2007, following the desicion in case of Resurfice Corp. v. Hanke [2007] 1 SCR 333:
}

(Stapleton, 2010, 5; Collins, 2011, 86.) 


\subsubsection{Iran}

In Iranian law, two situations are assumed depending on whether the independent tortfeasors causing the damage are Indirect Cause $^{2}$ or Direct Cause. In both cases, a causation link is established with both tortfeasors and therefore, both are liable.

The first situation in which multiple tortfeasors or causes, each separately, interfere with damage is allocated to independent "Interference of Indirect Cause and Direct Cause". When some person's act or omission as the indirect cause of the incident has set the grounds for a harmful act of the direct cause or when one is the direct cause of an incident and the other one is considered as reasonable and independent cause of the same incident due to leaving the duty, an independent causal link exists between the damaging incident and each tortfeasor. Thus, the liable tortfeasors of the incident will be responsible for the damages occurred to the victim jointly and severally (Article 673 of civil code ${ }^{3}$ ). For example, if someone is responsible for security of a property and fails in fulfilling his/her duty and another person wastes the property at the same time, the damaging incident is independently attributed to each mentioned person and each will have a joint and several perfect liability in compensation (Abbasloo, 2012; Abbasloo, 2010).

The second situation is related to independency of the tortfeasors or causes in causing the accident is "Interference of multiple independent causes". When multiple tortfeasors set the common ground for a damaging accident independently and separately by act or omission, considering that each tortfeasor is reasonably considered as the definite and independent cause of the damages, their joint and several liability must be considered (Abbasloo, 2012), because a causation relationship occurs among act/omission of each, and the only damage occurred to the damaged person. For example, while one acts upon committing an illegal act and another person in charge of supervision of the mentioned act fails to fulfil his/her duty, in case there is a damage, it is attributed to both tortfeasors and consequently their duty in compensation is joint and several ,and perfect.

\subsubsection{England}

In law of England, in cases where the damage can be attributed to multiple tortfeasors independently considering the causation relationship, depending on circumstances of the case, different tests may be applied for recognizing the cause and the liable person.

In some cases where different tortfeasors independently cause damage, the "materially increased risk approach" is applied. In cases where multiple tortfeasors are involved in the damage occurred to the victim and one tortfeasor has caused an increase in risk of damage occurrence or probability of its occurrence, the liability is attributed to the same tortfeasor. It means when each tortfeasor involved has the potential to cause the damage but negligence of the defendant considerably increases the creation probability of causation link, a strong causation relationship is created among defendant's fault and occurrence of damage which results in conviction of mentioned tortfeasor to compensation. For an instance, in case of "McGhee v. National Coal Board [1973] 1WLR1", a factory worker (the plaintiff) was infected with a skin disease. Existing evidences suggested that plaintiff's disease was caused by constant exposure of his skin to dust in work place. Because of lack of facilities to bathe after work, this dust remained on plaintiff's skin until the moment he arrived home. The plaintiff couldn't prove that he would not be infected with this disease in case of possibility of taking shower at work (But-for test ${ }^{4}$; however, the court issued a decision in favour of the plaintiff, because based on policy reasons and justice (Samuel, 2001), the court concluded that not availability of facilities for taking shower after work is a certain negligence done by the employer and has considerably increased the risk of damages (Cooke, Op. Cit).

Further, in some cases among several independent tortfeasors playing role in a damage, a tortfeasor with "material contribution" in damage is known liable; in cases where multiple tortfeasors are involved in damages occurred to the damaged party but contribution and interference of one of the tortfeasors compared to other tortfeasors is more important, the causation relationship is established with the acts or omissions of the one which is considered as the most important tortfeasor. It means its role is more significant than other tortfeasors e.g. "Wilsher v. Essex Area Health Authority [1988] 1 All ER 871", a three month old preterm born infant was supposed to be kept in oxygen device for care and maintenance, the physician in charge of taking care of the

\footnotetext{
${ }^{2}$ The concept of indirect cause is against the direct cause and stands for a person or factor who unlike the direct cause, has an indirect role in causing damage and has only made the premises for that. But the direct cause is directly involved in causing the damage. In law of England, no such a distinction exists between the factors involved in the accident.

3 "If an attorney with no delegate power leaves a work for whichhe/sheadvocates to a third person, each of the attorney and the third person will be responsible toward the client for the damages considered as a cause".

${ }^{4}$ This test is only applied in cases where just one tortfeasor is involved in the damage and the discussion is on liability or non-liability of the mentioned tortfeasor.
} 
baby gave him/her more than specified limit of oxygen in two stages, on negligence; as a result, the baby lost sight in both eyes. The baby's parents filed a claim against the physician and the hospital. The medical evidences showed that excessive oxygen entry was only one of the several factors which could cause infant's blindness and the blindness could have been due to 5 other weaknesses and diseases the baby had. Consequently, no firm reason arises implying that unusual amount of oxygen had created the incident. Ultimately, the court stated that the plaintiff had to prove that the physician's act was the main cause of damage and mere proving that (Administering too much oxygen) had increased the probability of damage was not a reason for sentencing in favour of the plaintiff. The baby's parents failed in proving the test required by the court and the plaintiff was not known liable for the incident (Elliott \& Quinn, Op.Cit; Owen, 2000).

In study of tortfeasors' independency, "new intervening act" must not be neglected. Where a tortfeasor has committed to a fault in damaging but another tortfeasor has interfered with incident after the first factor, it should be asserted that second tortfeasor has prevented impact of the first tortfeasor and he is liable himself for the damage. In other words, second tortfeasor has broken the causation chain with first tortfeasor and has prevented finding the liability attributable to the first tortfeasor (Barker \& Padfield, 1998; Black's Dictionary of Law, 2009, Oxford Dictionary of Law, 2013) e.g. “Thompson v. Blake- james [1998] Lloyd's Rep Med 187”, a physician, by negligence, did not recommend the parents to vaccinate the child. By child's infection with measles, his/her parents filed a claim against the physician. Since the child's parents did not rely on the physician's advices and had also referred to some other physicians, their claim against the first physician was rejected.

\subsection{Tortfeasor's Contribution}

In tortfeasor's contribution, situations are discussed where multiple tortfeasors cause damage together, in a way where each take responsibility for a part of damage load and the damage is the resulted from sum of their acts. Hence, there has been one damage in this case, but each tortfeasor has no independency in causing the damage and complements another tortfeasor.

\subsubsection{Iran}

In law of Iran, in cases where multiple tortfeasors have caused damages together, various situations have been considered where it is important whether to be indirect cause or direct cause and their interference manner.

Sometimes, the damage is the result of contribution of direct and indirect causes. When a damaging accident is created by act of some person as the direct cause and act or omission of another person as the indirect cause, in accordance with Article 526 of Iranian Islamic Penal Code, liability of each of direct cause and indirect cause will be as much as their impacts on accident. It means that causation relationship with each of them depends on their impact on the damage. For example, when one (indirect cause) digs a well and the other one (direct cause), drops a passer-by into that well, the opinion of judicial expert indicates how much involvement of each and as a result, their liability is. But if the direct cause is an automatist, insane, etc., only the cause of the incidence is known liable. On this basis, when a mature and wise person trains a young child and causes damages to the other through him/her, the only person responsible for compensation is the mature and wise person himself.

In addition, sometimes it is the "Contribution of multiple direct causes" that results in damages. When two or multiple direct causes jointly cause an accident, in accordance to Article 527 of Iranian Islamic Penal Code, their liability will be as much as their effect on the accident, because causation relationship with each of them depends on their impact on the accident e.g. when two people drop an object from a place together and result in financial and life loss to the damaged party, expert opinions will determine their impact on the accident then their responsibility in compensation.

"Concurrent Indirect Causes" is also another state in which contribution of the totfeasors or causes results in damages. A case where multiple indirect causes provide the premises of damage jointly and with intermediaries with taking an action, in accordance with Article 533 of Iranian Islamic Penal Code, in case of gathering the causes, regardless the impact of each, compensation will be done by them equally ${ }^{5}$. For example, when two or multiple people set a fire in a public passage together which spreads to other places with the wind and cause damages, each of them must equally participate in compensation of the damages ${ }^{6}$.

\footnotetext{
${ }^{5}$ The reason why the legislator has neglected determining the impact of each tortfeasor on this incident seems to be the difficulty in accurate diagnosis of the impact and role of tortfeasors each of which are indirectly involved in damages.

${ }^{6}$ In this case, the legislator has not used the same approach used for the "contribution of indirect and direct cause". Because determining the effect of two indirect causes (who indirectly have caused damages) is more difficult than determining the impact of two direct causes (which directly had roles in occurrence of accident). Hence, the legislator has applied various approaches about contribution of two causes, to prevent taste expertise and judgements.
} 
In addition to what was noted, a contribution of causes in some cases is taken place in the form of contribution of "Consecutive Indirect Causes". Whenever each of the two or multiple causes involved in a damaging incident commits an act or omission which sets the grounds for the incident one after another and consequently result in a unit incident, according to article 535 of Iranian Islamic Penal Code, the liability is attributed to the cause who has had the First Influencing (Abbasloo, 2012). For example, a case where someone digs a puddle and the other one puts a stone next to it, the person putting the stone is liable.

\subsubsection{England}

Apparently, no various approaches observed on this case in law of England; in fact, one approach is followed and when the damage is the result of collective performance of the tortfeasors causing the damage, liability of each tortfeasor will depend on its impact on occurrence of the damage. However, determining the exact amount of involvement or impact of each tortfeasor on occurrence of incidents is not always easily done (Cook, 2010). For example, the case of "Fitzgerald v. Lane 1987" can be mentioned. In this case, the damages were due to negligence of the plaintiff and the defendant. Namely, the damages were due to contribution of the plaintiff with two defendants. Therefore, the court attributed half of the liability to the plaintiff and the other half to the defendants of the case (Elliott \& Quinn, 2009).

Yet, in cases where the role of one tortfeasor in occurrence of damage is to the extent that it can be stated the second tortfeasor is under the effect of first tortfeasor which results in damages, liability of compensation is with the major tortfeasor or the one who has set the grounds for interference of the other. For an instance, in "Corr v. IBC vehicles Ltd. [2008] 2 All ER 943", plaintiff's husband became psychologically ill due to a terrible accident and as a result, committed suicide 6 months later. The court recognized the defendant liable for death of the mentioned person and did not accept the defendant's argument stating that suicide is voluntary which has cut the causation relationship between the accident and plaintiff's death, because it recognized the suicide to be as a result of depression due to the accident.

\subsection{Tortfeasor's Seperate Impact}

In this case, each tortfeasor involved in the incident separately damages the victim. Therefore, unlike the cases were discussed in independency of tortfeasors, multiple damages (not one) have been occurred, each attributed to a separate tortfeasor.

\subsubsection{Iran}

In cases where multiple tortfeasors put several separate impacts on the damaged party, the causation relationship is established among each tortfeasor with damages he has caused himself.

The first situation in which impact of causes in causing damage is a separate impact, is the "Interference of separate indirect causes and separate direct causes". Whenever each of indirect cause and direct cause separately damage a damaged party, each tortfeasor is known responsible for his own action. Thus, in an accident caused by indirect cause, causation relationship is only established with his own action and in an accident in which direct cause is involved, he will be responsible for compensation himself, because the damaging accident is not the result of real gathering of indirect cause and direct cause to be able to attribute responsibility of compensating the whole damages jointly to two tortfeasors and divide the whole damages among them. However, if calculation of the damages caused by each party is impossible, each of them will pay for half of the damages (Abbasloo, 2012). For example, if someone hurts another one as a direct cause, and another person causes deterioration of the damaged party's condition as indirect cause, the direct cause will be responsible for the damages caused by the hit and indirect cause will be responsible for increase in amount of damage. But if accurate calculation of the damages each have caused is not possible, the whole damage is divided between them ${ }^{7}$.

Further, a separate impact of tortfeasors in causing damages in some other cases is in the form of "multiple separate causes". When each of the two or multiple direct causes damage one damaged party separately by doing an action and the accidents caused by the mentioned tortfeasors are not related to each other, in this case, regardless concurrently or subsequently the accidents are occurred, a causation relationship will be established among the damages caused by each direct cause with his own action (Abbasloo, 2010). For example, when a vehicle hits a pedestrian and puts the mentioned pedestrian on the way of other people, where it is visible in the terms of location and then the next vehicle causes a damage to the pedestrian, each direct cause is liable for the

\footnotetext{
${ }^{7}$ There should be a distinction between distributing the liability and attribution of liability (or causation relationship) and it should not be ignored that distributing the damages equally does not mean the equal role of the parties in the accident and their equal liability. But, impossibility of determining amount of damages causes which we know the damagers equally liable for damage compensation rather than knowing their liability equal.
} 
damage he has caused himself ${ }^{8}$. However, if accurate amount of the damages each has caused cannot be determined, direct causes must compensate for the damages equally.

\subsubsection{England}

When two or multiple separate tortfeasors cause different damages to a damaged party, each tortfeasor is responsible for the damages he/she has caused. However, if accurate attribution of each accident to the damage tortfeasor cannot be determined for some reasons such as complexity of the tortfeasors involved in a damaging accident or scientific complexity, the contributing factors must be equally shared in damages ${ }^{9}$. For example, in case of "Fitzgerald v. Lane [1987] QB 781", the plaintiff walked into a crowded road while the light was red and was thrown to other side of the road in a collision by a moving car and then, he was hit by another automobile which caused him more injuries. Since it was unclear how much the role of each plaintiff was in the damages, the court ordered that the plaintiffs were equally responsible (Owen, 2000).

\section{Materials and Methodology}

This study was conducted in 2014-2015. Data were collected through Acts and Case law of Iran and England, as well as referring to related legal books and papers. Present study was analysed in a comparative study of law of the two countries i.e. Iran and England. Hence, this research is a descriptive-analytical study.

Considering the difference in law of Iran and England which is rooted in their differences in belonging to two legal families of Civil Law and Common Law, case law or precedent in law of England and Act in law of Iran are considered as the most important sources of law. Thus, although Act in England and judicial precedent in Iran are not generally ineffective and are used as a supplementary and subsidiary source, but what is of the highest importance for recognizing the law of Iran and England respectively are Acts and Case Law. For the same reason, study of the law of England in following article is primarily based on Case Law and study of Iranian law is on basis of civil and criminal Acts.

As it was noted earlier, law of Iran belongs to legal family of Civil law and law of England belongs to Common law family. Considering this, views of the two countries toward legal issues is different; so that, Iranian law can observe making general rules in the form of Acts favourable, while the law of England pays less attention to making general rules. The existing differences were determined at the beginning of the paper in introduction. Second part concentrates on the state of negligence in tort law, and causation in negligence law of Iran and England. In this regard, state of negligence and the liability caused by that in general rules of tort law, namely fault-based liability and strict liability were studied first and then, necessity and state of causal link in negligence liability was discussed. Third part of this paper focused on the main discussion and compared the causal link between the two countries. However, causation in present study is merely investigated under the state where multiple tortfeasors are involved in the damage; therefore, the state where only one tortfeasor is involved in the occurrence of the damage and the discussion is over whether a causation poses a relationship between the mentioned tortfeasor and the damage or not, is not subject of this study. Furthermore, the state where only one factor is responsible for the damage but the mentioned tortfeasor cannot be identified from among multiple similar tortfeasors for different reasons, is also out of the scope of this study. In study of causation, multiplicity of the factors involved in damages is also discussed in three states of "Independency of tortfeasors", "Contribution of tortfeasors" and "Separate impact of tortfeasors". In independency, a damaging accident is independently attributable to two or multiple tortfeasors. But, the damage in Contribution is occurred as a result of contribution of tortfeasors. Each tortfeasor in Separate impact of tortfeasors has a separate impact and causes separate damages.

\footnotetext{
${ }^{8}$ This state should not be considered the same as uncertain cause, because in an uncertain cause only one tortfeasor is the cause of damage but it is impossible to determine that tortfeasor, while multiple tortfeasors pose a role in causing multiple independent damages.

${ }^{9}$ It seems that, in this case, the same distinction discussed among "division of liability" and "attribution of liability" also exist in law of England.
} 
Figure1. State of Causation in Tort Law: Case of Multiple Tortfeasors

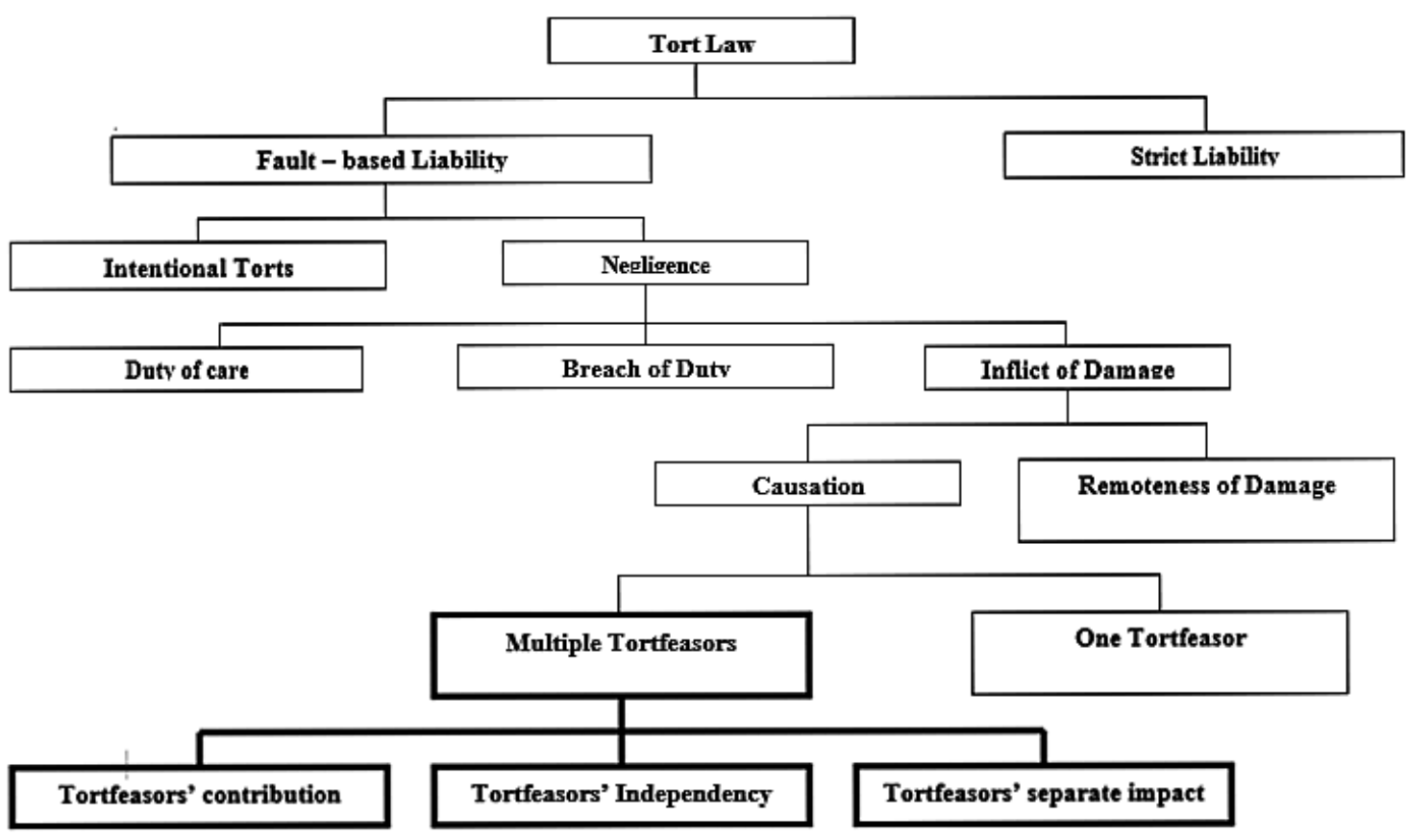

Figure 1. State of causation in tort law: case of multiple tortfeasors

\section{Results and Discussion}

In law of Iran, interference of different tortfeasors which have been involved in occurrence of damage independently, contributory or with separate impacts may be direct or indirect; so that, the cause with direct impact on accident is called the "direct cause" and the cause with indirect causal link is called the "indirect cause"; while, no such distinction appears between direct or indirect effect of causes or the tortfeasors in law of England.

In addition, only one fixed solution in Iran exists for each situation in which multiple factors have been involved in the occurrence of damage. In other words, the liable cause can be identified easily, according to what was noted earlier, by determining the situation in which different factors have played a role; while in England, a definite response and a fixed solution cannot be always obtained, even by determining the type of interference and the situation in which different tortfeasors have had a role in. The reason for this difference between law of Iran and England is that law of Iran belongs to Civil Law family in which stability of the legal rules is one of important principles and efforts arise to avoid changing the legal principles and rules considering characteristics of each case as much as possible. On the contrary, there is an attempt to pay attention to special features of the same case and avoid making general and unchanging rules in law of England.

Despite the above-mentioned difference between the law of Iran and England, views of the two countries about different states of involvement in damaging are not much far from each other and presented approaches are close in all states, namely the contribution of tortfeasors and their separate impacts, except the tortfeasor's independency state: 1 . When two or multiple tortfeasors independently cause a damage, law of the two countries adopt different approaches: the Iranian law, however, emphasises the joint and several liability of the tortfeasors and the law of England may apply various tests depending on the circumstances. 2. But about contribution of tortfeasors, division of responsibilities among the tortfeasors is mentioned as the general rule in both countries, except when one tortfeasor has forced the other one to interfere with the accident under his/her own influence and dominance which in this case, both countries know the major tortfeasor, who has set the grounds, as the responsible and believe that there is a causation relationship with it. However, law of Iran has two differences with law of England in study of tortfeasors' contribution. First, when multiple indirect causes have been involved in the accident one after the other, the tortfeasor that has impacted earlier is known liable. Secondly, when multiple direct causes are involved in accident, division is in proportion to the fault. 3 . In cases where different tortfeasors pose separate impacts on the damaged party, law of the both countries know each tortfeasor liable for 
the damage he/she has caused. However, if it is impossible to separate the damages, both countries believe the equal responsibility of damagers in compensation to be reasonable.

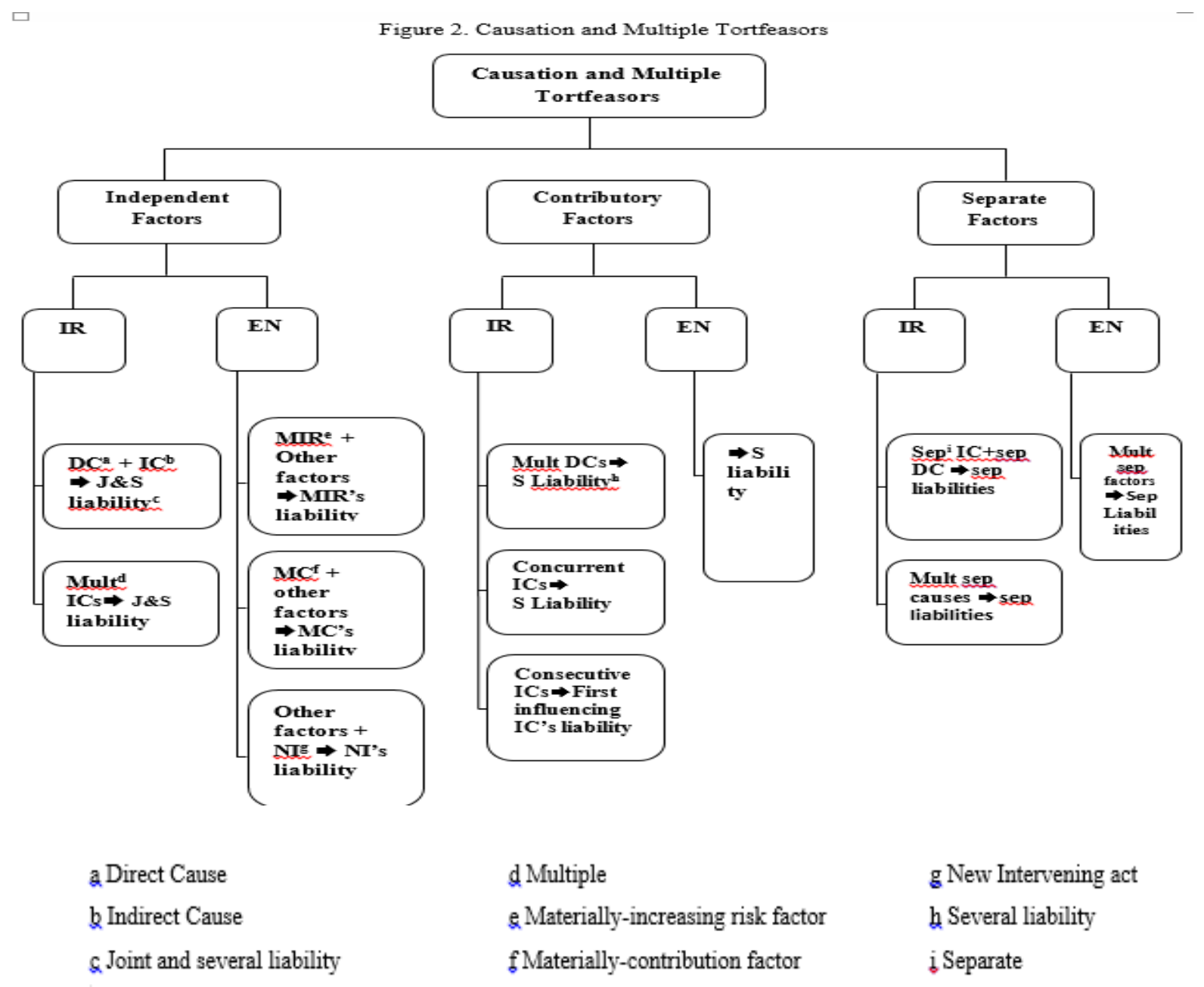

Figure 2. Causation and multiple tortfeasors

What is common in almost all works and researches conducted in this area is lack of a comparative study and a comparison between the law of Iran and England in this field. In addition, what is discussed and studied in this paper is also different from other available works from other aspects. For example, the main focus of Hylton and Lin (2013) is on care and causal link and it is different from present research scope in this respect, because present study has considered various states of causation in cases where more than one tortfeasor is involved in the damage. Meier (2011) has also studied Cause in Fact and Cause in Law in Supreme Court of USA, while cause in fact is merely considered in what the researchers is investigated. In Knutson's study (2010), despite focusing on cause in fact and having more similarity with this research compared to other researches, is related to the law of Canada.

In addition to the works mentioned above, there are also other researches with much more similarities with present study, but some of their characteristics differentiate the mentioned works from present research e.g. Abbasloo (2010), despite paying attention to liability distribution, has not paid attention to negligence independently and has considered no distinction among the estate in which one cause is involved with the estate with multiple causes in liability division. Although Goepel and Batkin (2009) have considered Cause in Fact while more than one tortfeasors are involved in the damage, but they pay attention to sufficiency and insufficiency of the tortfeasors instead of differentiating among three states of independency, contribution and separate impact of the tortfeasors. Moreover, these researches have differentiated between divisible injuries and invisible injuries, while this differentiation is not of much importance to present study. Yet, Hitchcock and 
Stirling (2012) have focused on multiple tortfeasors, but their main focus is on the role and impact of intervening act and it is different with this paper in this respect, because present study examined the impact of intervening act as a subsidiary fact.

One of the most important obstacles faced by the researchers is the lack of similar comparative works; although there are roughly similar works in this field, but the mentioned works are usually not comparative and none of them have compared the law of Iran and England. The second limitation of this research is related to the law of Iran: since Negligence is not independently studied in civil codes of Iran, Iranian law scholars generally feel no need to study the specific role of causal link in negligence liability. This matter causes access to similar and close resources in law of Iran to be almost impossible.

\section{Conclusions}

Unlike what was expected, differences between the law of Iran and England in legal strategies applied to explain causation and its concept is less than their similarities; although, the liability caused by negligence is not studied independently, but its position in law of Iran and England is not much different and it is considered as fault-based liability in both countries. Moreover, despite the differences in law of Iran and England in how to express different situations of "interference of multiple tortfeasors in the damage", common points among the law of Iran and England are not low and the law of the two countries in this field can be viewed from the same perspective so that the comparative studies can be conducted on three states of independency, contribution and separate impact of the tortfeasors. For the same reason, the researchers approve that due to the considerable similarities between the law of the two countries, the law of England and its strategies can be considered as a supplementary for the law of Iran so that the Iranian judges will be able to use the law of England in cases where no strategy has been presented in this field in law of Iran or where the existing strategies do not seem to be consistent with conditions of the case and consequently, the verdicts of the court on these cases will be more consistent with justice and the situation dominating the case. However, indulgence in this field is not advisable because despite the similarities, it should not be neglected that the law of Iran, unlike England, does not deem paying excessive attention to features of each case appropriate. Hence, modelling and utilization of English law's strategies must not be imitated.

Considering that this research studies the causation relationship while multiple factors are involved in damages, the study of causation relationship while only one factor is involved in the damage can be proposed as a suggestion for another comparative work in law of Iran and England.

\section{References}

Abbasloo, B. (2010). Apportionment of Liability. Azad Legal Research Journal, (8-10), 195-213.

Abbasloo, B. (2012). Civil Liability with a Comparative Approach (1st ed.). Tehran, Iran: Mizan.

Bahrami Ahmadi, H. (2010). Responsabilité Civile (2nd ed.). Tehran, Iran: Mizan.

Barker, D., \& Colin, P. (1998). Law Made Simple (10th ed.). Oxford, England: Made Simple Books.

Black's Dictionary of Law (9th ed.). (2009). New York, U.S.:West.

Collins, L. M. (2011). Causation, Contribution and Clements: Revisiting the Material Contribution Test in Canadian Tort Law. Tort Law Review, 19, 86-88. Retrieved from http://ssrn.com/abstract=1913290

Cooke, J. (2010). Law of Tort (9th ed.). London, England; Longman.

Crowne, E., \& Ha-Redeye, O. (2012). Clements v. Clements: A Material Contribution to the Jurisprudence - The Supreme Court of Canada Clarifies the Law of Causation. University of Western Ontario Journal of Legal Studies, 2(2).

Elliot, C., \& Quinn, F. (2009). Tort Law (7th ed.). London, England: Longman.

Goepel, R., \& Batkin, S. (2009). Apportionment of Damages between Multiple Tortfeasors. Cwilson. Retrieved from

https://www.Cwilson.com/publications/insurance/apportionment-of-damages-between-multiple-tortfeasors. pdf

Halbersberg, Y. (2013). Toward a New Paradigm for Multiple-Victim Torts: The Problem of Victims Heterogeneity.

Hitchcock, P., \& Stirling, C. (2012). Drawing the Fault Line: Multiple Tortfeasors and Intervening Acts. Cloisters.

Retrieved

from http://www.cloisters.com/seminar-items/2012-november-drawing-the-fault-line.pdf

Hylton, K. N. (2013). Causation in Tort Law: A Reconsideration. Boston University. School of Law, Law and Economics Research Paper No. 13-30; Retrieved from http://ssrn.com/abstract=2297543 
Hylton, K. N., \& Lin, H. (2013). Negligence, Causation, and Incentives for Care. Boston University School of Law, Working Paper No. 11-15. http://dx.doi.org/10.1016/j.irle.2013.04.004

Imami, S. H. (2011). Civil law (Vol. 1., 30th ed.). Tehran, Iran: Islamic.

Katouzian, N. (2014). Civil Laiability: Extra-Contractual Obligations (Vol. 1., 11th ed.). Tehran, Iran: Tehran University Press.

Knutsen, E. S. (2010). Clarifying Causation in Tort. Dalhousie Law Journal, 33(1), 153-188. Retrieved from http://ssrn.com/abstract=1448828

Meier, L. (2011). Using Tort Law to Understand the Causation Prong of Standing. Fordham Law Review, 80(101), 101-159. Retrieved from http://ssrn.com/abstract=1639598

Noee, E. (2015). Negligence and Duty of Care in Tort(s) Law of Iran and England (1st ed.). Tehran, Iran: Majd.

Owen, R. (2000). Essential Tort Law (3rd ed.). London, England: Routledge-Cavendish.

Qasemzade, M. (2010). The Law of Tort (9th ed.). Tehran, iran: Mizan.

Safai, S. H., \& Rahimi, H. (2014). Civil Laiability: Extra-Contractual Liability (6th ed.). Tehran, Iran: Samt.

Samuel, G. (2001). Law of Obligation and Legal Remedies (2nd ed.). London, England: Cavendish.

Stapleton, J. (2010). Factual Causation. Federal Law Review, 38(3), 467-484. Retrieved from http://ssrn.com/abstract $=1757302$

Wright, R. W. (2011). Proving Causation: Probability versus Belief. In R. Goldberg (Ed.), Perspectives on Causation, Ch. 10. Hart Publishing. Retrieved from http://ssrn.com/abstract=1918474

Yazdanian, A. (2007). The realm of Tort Law (1st ed.). Tehran, Iran: Adabestan.

\section{Copyrights}

Copyright for this article is retained by the author(s), with first publication rights granted to the journal.

This is an open-access article distributed under the terms and conditions of the Creative Commons Attribution license (http://creativecommons.org/licenses/by/4.0/). 